RASĀYAN J. Chem.

Vol. 13 | No. 1 |395 - 404| January - March | 2020 ISSN: 0974-1496 | e-ISSN: 0976-0083 | CODEN: RJCABP

RJC http://www.rasayanjournal.com http://www.rasayanjournal.co.in

\title{
GROWTH, CHARACTERIZATION OF Mn(II) DOPED Zn(II) L-HISTIDINE HYDROCHLORIDE MONOHYDRATE COMPLEX CRYSTALS
}

\author{
V. Parvathi ${ }^{1, *}$, J. Sai Chandra ${ }^{2}$, Y. Sunandamma ${ }^{2}$ and H.Ananda Lakshmi ${ }^{3}$ \\ ${ }^{1}$ Freshmen Engineering Department, Lakireddy Balireddy College of Engineering, Krishna, \\ Andhra Pradesh-521 230, India \\ ${ }^{2}$ Dept. of Chemistry, Acharya Nagarjuna University, Nagarjuna Nagar, Guntur, \\ Andhra Pradesh-522 510, India \\ ${ }^{3}$ Department of Chemistry, Faculty of Engineering and Technology, Annamalai University, \\ Annamalai nagar, Chidambaram, Tamilnadu, INDIA. 608002 \\ *E-mail: parvathi.sv14@gmail.com
}

\begin{abstract}
$\mathrm{Mn}(\mathrm{II})$ ions are incorporated in $\mathrm{Zn}$ (II)L-Histidine hydrochloride crystals by doping. Crystals are grown by using the technique of slow evaporation from aqueous solutions at room temperature. Thus developed crystals are characterized by powder X-Ray diffraction, EPR, FTIR, UV-VIS and Vicker's microhardness studies.
\end{abstract}

Keywords: L-Histidine, EPR, XRD, Microhardness.

(C) RASĀYAN. All rights reserved

\section{INTRODUCTION}

Most of the advanced technologies are making use of crystals developed from their aqueous solutions. Doping involves addition of impurities in very low concentration to a substance in order to endorse specific desired properties and to make them better materials for technological applications. ${ }^{1-4}$ Significant attention was paid for this purpose to study the impact of doping on several crystalline systems as it can bring remarkable changes in electrical and optical properties of crystals that are extensively used in technology.

Amino acids are found captivating as they are devoid of strong conjugated bonds and due to their chirality in molecules, zwitterionic character making them potential candidates for NLO applications. ${ }^{5}$ Over the past few decades metal, ion-amino acid interactions gained technological importance as nonlinear optical materials. Metal ion doped amino acid complexes have the advantages of an organic segment of amino acid and inorganic segment i.e., metal ions and are appraised as most satisfactory materials for second harmonic generation (SHG) properties. ${ }^{6}$ Apart from the significant biological role of amino acid - metal complexes in the areas of pharmacy, nutrition and agronomy, they also play a prominent role in advanced fields of technology like lasers, optical storage and communication. ${ }^{6}$

Structurally amino acid L-Histidine satisfies the indispensable condition to exhibit NLO properties with chirality and ability to crystallize in non-centrosymmetric space group. ${ }^{7}$ L-Histidine had been quite interesting compound with its identification as nonlinear optical activity in L-Histidine tetra floroborate which was found encouraging. ${ }^{8}$ A considerable number of compounds of L-Histidine were announced to exhibit high second-harmonic conversion efficiency. ${ }^{9}$ In view of amino acid's potential ability to bind to metal ions, L-Histidine complexes are reported to play a prominent role in biological processes. ${ }^{10,11}$ Zinc is a trace element biologically and participates in diverse processes in animal and human physiology. ${ }^{12}$ It is essential for the catalytic activity of about 100 enzymes ${ }^{13,14}$ and plays a significant role in the synthesis of proteins, DNA, immune function and healing wounds. ${ }^{15,16}$ Zinc complex of Histidine [ $\mathrm{Zn}$ (His) 2 ] was

Rasayan J. Chem., 13(1), 395-404(2020)

http://dx.doi.org/10.31788/RJC.2020.1315197

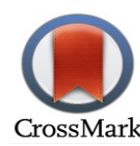


RASĀYAN J. Chem.

Vol. 13 | No. 1 |395 - 404| January - March | 2020

found to possess significant biological influence, enriched bioavailability with an antioxidant potential to protect cortical neurons from damage caused by oxidative stress compared to other zinc salts. ${ }^{17}$ Manganese is an important element for the regular functioning of various physiological processes like the development of all organisms. It plays a key role to integrate metalloproteins that are significant in metabolic processes. Reports of Mn (II) doped amino acids are available. Reported EPR studies on manganese incorporated into crystals of $L$-Alanine indicated that $\mathrm{Mn}$ (II) ions were at interstitial sites which are magnetically equivalent in unit cell as Manganese chloride in small concentrations while higher Manganese chloride concentrations produced clusters of manganese in doped crystals of $L$-Alanine at interstitial sites. ${ }^{18}$ EPR studies of Mn(II) doped monohydrated $L$-asparagine crystals also indicated that $\mathrm{Mn}$ (II) ions were incorporated into two chemically distinct sites in asparagine crystals. ${ }^{19}$

As far as our literature search goes, two crystal systems, a complex of Zinc (D, L-Histidine) ${ }_{2}$ with the incorporation of $\mathrm{Cu}(\mathrm{II})$ ions ${ }^{20}$, Zinc L-Histidine complex with $\mathrm{Mn}$ (II) ion as dopant ${ }^{21}$ were reported. The complex of Zinc (D, L-Histidine) ${ }_{2}$ with $\mathrm{Cu}$ (II) ion as dopants were characterized by EPR, X-ray diffraction and calorimetric studies. Histidine ligand was reported as bound to $\mathrm{Zn}(\mathrm{II})$ ion through imidazole and amino nitrogens and carboxylate oxygen. ESR studies were carried out on Zinc L-Histidine complex with $\mathrm{Mn}$ (II) ion as a dopant. No other transition metal ions were reported as dopants on LHistidine complexes and hence Mn(II) doped Zn(II) L-Histidine hydrochloride monohydrate complex is a novel crystal system grown and characterized in our laboratory.

In the present study, complex crystals of $\mathrm{Mn}$ (II) ion doped $\mathrm{Zn}$ L-Histidine were developed by the technique of slow evaporation and characterized by a variety of spectroscopic techniques like powder XRay diffraction analysis, Electron paramagnetic resonance (EPR) FT-IR, UV-Vis spectra and microhardness studies analysis. The second harmonic generation (SHG) efficiency of the grown crystals was confirmed by Nd: YAG laser study. Scanning electron microscopic, thermogravimetry and differential thermal analysis and chemical etching studies were also carried out on the grown crystals to ascertain their thermal and mechanical stabilities.

\section{Material and Methods}

\section{EXPERIMENTAL}

$\mathrm{Zn}$ (II) L-Histidine hydrochloride monohydrate crystals, hereafter called $\mathrm{ZnLHICl}$, were grown by slow evaporation at room temperature from the aqueous, equimolar and equivolume solutions containing Zinc chloride hexahydrate $\left(\mathrm{ZnCl}_{2} \cdot 6 \mathrm{H}_{2} \mathrm{O}\right)[0.244 \mathrm{~g}, 0.1 \mathrm{~mol}]$ and L-Histidine hydrochloride monohydrate $\left(\mathrm{C}_{6} \mathrm{H}_{12} \mathrm{ClN}_{3} \mathrm{O}_{3}\right)[0.209 \mathrm{~g}, 0.1 \mathrm{~mol}]$. Mn (II) doped $\mathrm{Zn}(\mathrm{II}) \mathrm{LHICl}$ crystals were grown by adding $0.01 \mathrm{~mol} \%$ of $\mathrm{Mn}$ (II) chloride solution to the growth solution.

\section{General Procedure}

The solution was constantly stirred for 2 hours with a magnetic stirrer to obtain a homogeneous mixture and was filtered through a Whatman filter paper. The solution was then transferred into a fresh $100 \mathrm{ml}$ beaker and covered with a porous aluminum foil before leaving it for slow evaporation at room temperature. Colorless crystals of Mn(II) doped ZnLHICl shown in Fig.-1 with good external morphology and of various sizes were obtained in about 40 to 45 days. The crystals were washed with acetone and dried. Dimensions of the well-grown crystal were $10 \times 9 \times 6 \mathrm{~mm}^{3}$.

\section{Analytical Discussion}

XRD spectrum was recorded on PHILIPS Make PW1830 X-ray Diffractometer with $\mathrm{K} \alpha(\lambda=1.54056 \AA)$ radiation, EPR spectrum was recorded on JEOL Make JES-FA 200 EPR Spectrometer at room temperature, FT-IR spectrum was recorded on Thermo Nicolet 6700 in the range $400-4000 \mathrm{~cm}^{-1}$ using $\mathrm{KBr}$ pellets, UV-VIS spectrum was recorded in the range of $200-1400 \mathrm{~nm}$ on JASCO V670 Spectrophotometer, ${ }^{13} \mathrm{CNMR}$ spectrum was recorded on Bruker AvII-400 MHz, TG/DTA analysis on SII Nano Technology model TG/DTA 6200. SEM studies by SEM Hitachi-S520, Microhardness studies by HM-210 Vicker's microhardness tester, Chemical Etching studies by Metallurgical microscope (Axioskop 40 MAT), NLO activity by Q switched High energy Nd: YAG Laser- Quanta Ray: Model Lab-170-10 Energy $-850 \mathrm{~mJ} / 1064 \mathrm{~nm}$. 
RASĀYAN J. Chem.

Vol. 13 | No. 1 |395 - 404| January - March | 2020

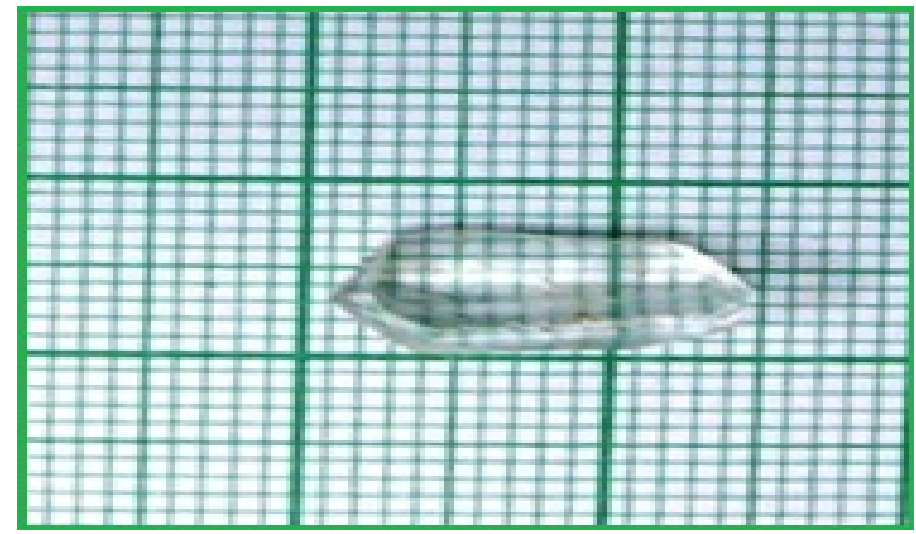

Fig.-1: Mn(II) Doped ZnLHICl Crystal as Grown

\section{Powder X-ray Diffraction Studies}

\section{RESULTS AND DISCUSSION}

Powder XRD analysis is a powerful tool for structural characterization and the influence of doping on the crystal structure. Highly crystalline phases with single-phase nature are confirmed by the sharp and clear pattern of powder XRD spectrum of Mn (II) doped ZnLHICl crystals shown in Fig.-2. JCPDS Programme was used to evaluate lattice parameters of crystals. Reported X-Ray patterns and unit cell parameters are available for L-Histidine hydrochloride monohydrate and Zinc L-Histidine complex. ${ }^{22,23}$ The study revealed that major changes are not found in lattice cell parameters due to complexation compared to undoped LHICl. Similar trends were observed for $\mathrm{Mn}(\mathrm{II})$ doped $\mathrm{ZnLHICl}$ complex crystal. Evaluated lattice cell parameters for $\mathrm{Mn}(\mathrm{II})$ doped $\mathrm{ZnLHICl}$ were $\mathrm{a}=1.5275, \mathrm{~b}=0.8946, \mathrm{c}=0.6811 \mathrm{~nm}$ and $\mathrm{V}=$ $930.84 \AA^{3}$ Inclusion of $\mathrm{Mn}(\mathrm{II})$ in the complex crystal improved the strength of interactions which also was confirmed by slight reduction in volume of doped complex crystal compared to LHICl. The reason for slight variations identified in unit cell parameters of $\mathrm{Mn}$ (II) doped $\mathrm{ZnLHICl}$ crystal compared to LHICl crystal is due to the adjustment of amino acid molecules inside interstitial voids instead of replacing metal ions at various lattice points/incorporation of metal ions into host lattice should have caused lattice strain. ${ }^{24,25}$ Small shift in the positions of peaks of XRD patterns of LHICl and metal ion-doped LHICL crystals indicate the single-phase nature of $\mathrm{Mn}$ (II) doped LHICl crystals. ${ }^{22,26,27}$ Lattice cell parameters for $\mathrm{L}-\mathrm{HICl}$ and $\mathrm{Mn}$ (II) doped ZnLHICl crystals are presented in Table-1. Values of $\mathrm{h} \mathrm{k} 1$ along with dspacings and $2 \theta$ values, both observed and calculated are presented in Table-2. From the XRD study, an orthorhombic system with space group $\mathrm{P} 2{ }_{1} 2_{1} 2_{1}$ was proposed for $\mathrm{Mn}(\mathrm{II})$ doped $\mathrm{ZnLHICl}$ crystals.

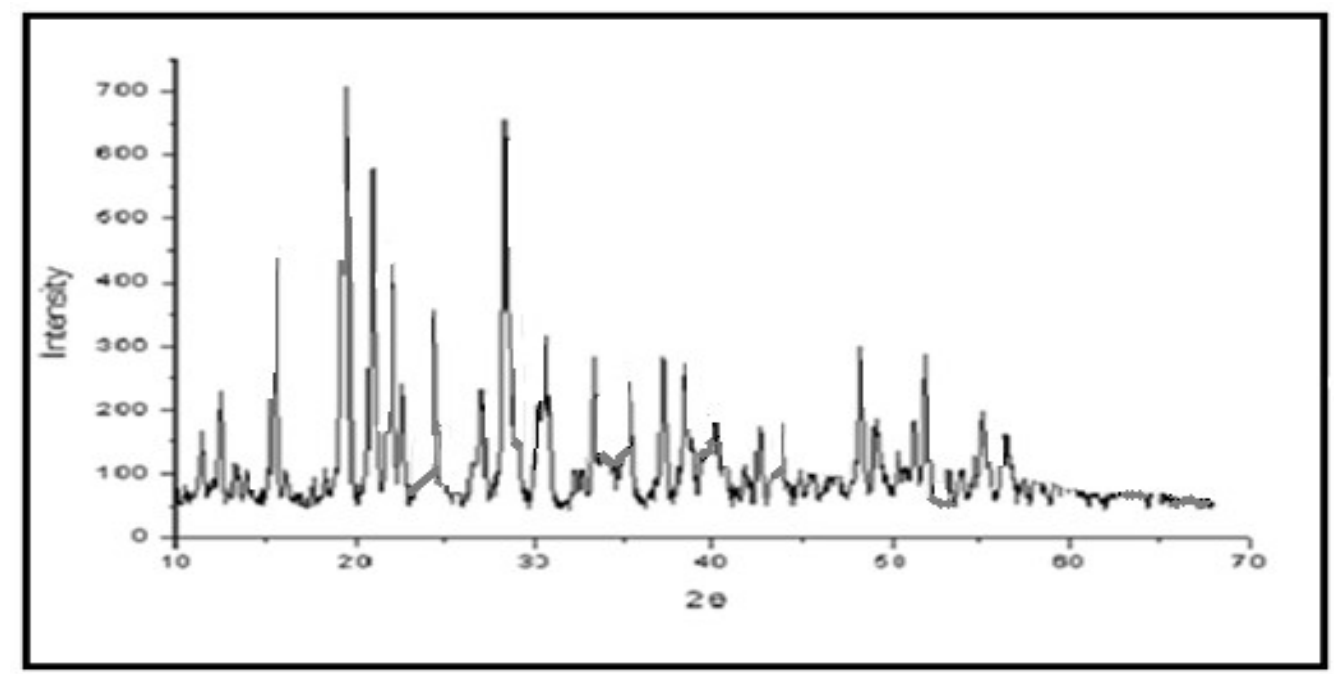

Fig.-2: Powder XRD Pattern of Mn(II) Doped ZnLHICl Crystal 
RASĀYAN J. Chem.

Vol. 13 | No. 1 |395 - 404| January - March | 2020

Table- 1: Lattice Parameters for LHICl and Mn(II) Doped ZnLHICl Crystals

\begin{tabular}{c|c|c|c|c|c}
\hline S. No. & $\begin{array}{c}\text { Name of } \\
\text { Compound }\end{array}$ & $\begin{array}{c}\text { Lattice Parameters } \\
(\mathrm{nm})\end{array}$ & Crystal System & $\begin{array}{c}\text { Space } \\
\text { Group }\end{array}$ & Volume $\left(\AA^{3}\right)$ \\
\hline \multirow{2}{*}{1.} & LHICl & $\begin{array}{l}\mathrm{a}=1.5301 \\
\mathrm{~b}=0.8921 \\
\mathrm{c}=0.6846\end{array}$ & Orthorhombic & $\mathrm{P} 2_{1} 2_{1} 2_{1}$ & 934.54 \\
\hline \multirow{2}{*}{2.} & Mn(II)doped & $\begin{array}{l}\mathrm{a}=1.5275 \\
\mathrm{~b}=0.8946 \\
\mathrm{c}=0.6811\end{array}$ & Orthorhombic & $\mathrm{P} 2_{1} 2_{1} 2_{1}$ & 930.84 \\
\hline
\end{tabular}

Table-2: Experimental and Calculated XRD Data of Mn(II) Doped ZnLHICl Crystal

\begin{tabular}{|c|c|c|c|c|c|c|}
\hline \multicolumn{2}{|c|}{$\mathrm{d}-\operatorname{Spacing}(\AA)$} & \multicolumn{3}{|c|}{ Indices } & \multicolumn{2}{|c|}{$2 \theta$ (degree) } \\
\hline Observed & Calculated & $h$ & $k$ & $l$ & Observed & Calculated \\
\hline 7.72 & 7.72 & 1 & 2 & 0 & 11.45 & 11.45 \\
\hline 7.07 & 7.07 & 0 & 1 & 1 & 12.51 & 12.51 \\
\hline 5.71 & 5.83 & 1 & 3 & 0 & 15.50 & 15.17 \\
\hline 4.53 & 4.49 & 2 & 3 & 0 & 19.56 & 19.72 \\
\hline 4.23 & 4.29 & 2 & 2 & 1 & 20.95 & 20.68 \\
\hline 4.04 & 4.07 & 3 & 0 & 0 & 21.93 & 21.77 \\
\hline 3.66 & 3.61 & 1 & 0 & 2 & 24.29 & 24.61 \\
\hline 3.47 & 3.47 & 3 & 3 & 0 & 25.62 & 25.61 \\
\hline 3.14 & 3.15 & 3 & 4 & 0 & 28.34 & 28.32 \\
\hline 3.07 & 3.06 & 2 & 2 & 2 & 29.05 & 29.14 \\
\hline 2.91 & 2.91 & 2 & 6 & 0 & 30.60 & 30.62 \\
\hline 2.63 & 2.60 & 4 & 3 & 1 & 34.01 & 34.36 \\
\hline 2.54 & 2.55 & 3 & 3 & 2 & 35.22 & 35.03 \\
\hline 2.41 & 2.42 & 3 & 4 & 2 & 37.25 & 37.07 \\
\hline 2.31 & 2.31 & 4 & 5 & 1 & 38.93 & 38.96 \\
\hline 2.21 & 2.21 & 1 & 4 & 3 & 40.62 & 40.75 \\
\hline 2.11 & 2.12 & 0 & 9 & 1 & 42.64 & 42.54 \\
\hline 2.06 & 2.07 & 0 & 8 & 2 & 43.71 & 43.49 \\
\hline 1.88 & 1.88 & 3 & 9 & 1 & 48.23 & 48.28 \\
\hline 1.75 & 1.75 & 5 & 0 & 3 & 52.00 & 52.03 \\
\hline 1.66 & 1.66 & 0 & 9 & 3 & 55.20 & 55.18 \\
\hline
\end{tabular}

Electron Paramagnetic Resonance (EPR) Studies

Variation in general characteristic properties of the host lattice can be detected by doping a trace amount of paramagnetic impurity into diamagnetic host lattice. High internal symmetry for the host lattice is observed in the case of diamagnetic host lattice due to completely filled external electronic shells. EPR of doped $\mathrm{Mn}(\mathrm{II})$ has been extensively investigated in a wide range of crystals with an objective to identify variations in phase transitions, site symmetry, orientations, and magnetic properties. ${ }^{28-32}$

Paramagnetism exhibited by Mn(II) doped crystal is due to the spin of electrons alone as a consequence of half-filled d orbital configuration which in turn gives zero value of orbital angular momentum. Prolonged spin-lattice relaxation times in ground state is the primary reason for well-resolved spectra of $\mathrm{Mn}$ (II) doped LHICl. ${ }^{33-35}$ Type of symmetry could also be elucidated from EPR studies as it's zero-field splitting is extremely sensitive to local field geometry. ${ }^{36}$ Three Kramer doublets which dissociate as 4D and 2D caused by spin-spin interactions are found with $\mathrm{Mn}$ (II) ion in the ground state. Application of external magnetic field causes further splitting of these doublets into six levels with consecutive separations as $g \beta B+4 D, g \beta B+2 D, g \beta B, g \beta B-2 D, g \beta B-4 D$. Hyperfine interaction with the nuclear spin of ${ }^{55} \mathrm{Mn}(\mathrm{I}=5 / 2)$ further allows the transition between these levels which gives five uniformly spaced lines each of which further resolve into sextet as a consequent 30 line pattern is observed in $\mathrm{Mn}$ (II) ion in its 
RASĀYAN J. Chem.

Vol. 13 | No. 1 |395 - 404| January - March | 2020

EPR spectrum. ${ }^{37}$ EPR spectrum of Mn(II) doped ZnHICL is shown in Fig.-3. Zn(II) is a $\mathrm{d}^{10}$ ion which is EPR inactive and no EPR signal can be expected for $\mathrm{Zn}$ (II) ions in the spectrum at room temperature. The resonance lines that appear in the EPR spectrum are due to the presence of Mn(II) ion as a dopant in the host lattice. Spin Hamiltonian is extensively used in the analysis of EPR of Mn(II) ion.

$$
\mathrm{H}=\mathrm{g} \beta \mathrm{BS}+\mathrm{SAI}+\mathrm{SDS}^{38,39}
$$

Where $\mathrm{g}$ is an isotropic factor, $\beta$ is Bohr Magneton, $\mathrm{B}$ is the external magnetic field, $\mathrm{S}$ is vector operator of electron spin momentum, A is hyperfine interaction parameter, I is vector operator of nuclear spin momentum and $\mathrm{D}$ is the zero-field splitting parameter. The EPR spectrum of $\mathrm{Mn}$ (II) doped $\mathrm{ZnLHICl}$ recorded at room temperature revealed a wide distribution of sites denoted by different degrees of distribution with a strong signal at $\mathrm{g} \approx 2.0$, which can be attributed to enhanced spin-lattice relaxation. Near octahedral symmetry of $\mathrm{Mn}(\mathrm{II})$ ions of the host, lattice was confirmed based on the obtained $\mathrm{g}=$ 1.9862 and $\mathrm{A}=103 \times 10^{-4} \mathrm{~cm}^{-1}$ which are due to the transitions among the energy levels of lower Kramer's doublet. ${ }^{38-40}$ The $\Delta \mathrm{g}$ value calculated for hyperfine splitting suggested the nature of bonding. The negative shift in $g$ value compared to the free-electron value (2.0023) indicates ionic nature, whereas positive shift indicates the covalent nature of the bond. Positive $\Delta \mathrm{g}$ value in the present investigation suggested the covalent nature of bonding in the Mn(II) doped $\mathrm{Zn} \mathrm{LHICl}$ crystals.

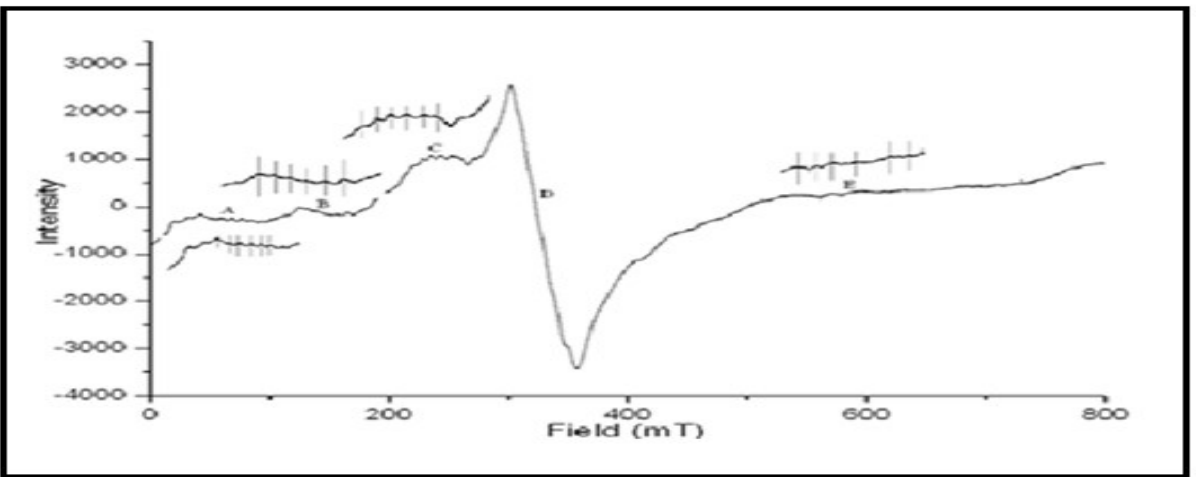

Fig.-3: Polycrystalline EPR Spectrum of Mn(II) Doped ZnLHICl Crystal $(v=9.152104$ GHz)

\section{FT-IR Spectral Studies}

Analysis of the Infrared spectrum is a powerful tool to identify various functional groups in the developed crystals. Figure-4 reveals various frequencies of spectral bands for $\mathrm{Mn}(\mathrm{II})$ doped $\mathrm{ZnLHICl}$ crystals. These were compared and interpreted with the known spectra of L-Histidine. ${ }^{41-43,27}$

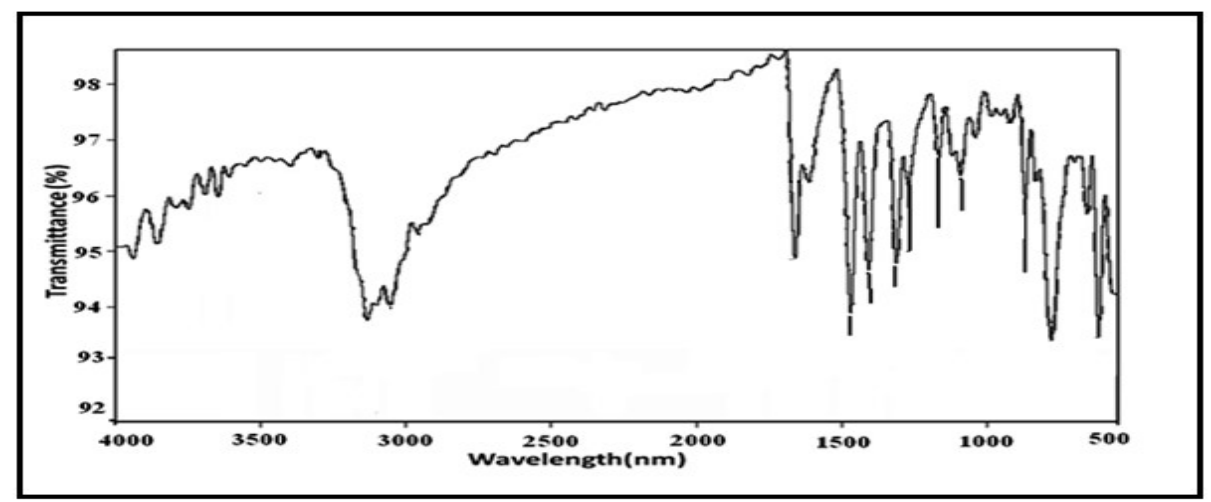

Fig.-4: FTIR Spectrum of Mn(II) Doped ZnLHICl Crystal

FTIR spectrum of Mn(II) doped ZnLHICl recorded a strong and intense peak at $3398 \mathrm{~cm}^{-1}$ assigned to O$\mathrm{H}$ stretching of carboxylic acid/ presence of water molecule in the crystal. The peak at $3132 \mathrm{~cm}^{-1}$ was 
RASĀYAN J. Chem.

Vol. 13 | No. 1 |395 - 404| January - March | 2020

assigned to $\mathrm{NH}$ in an amine functional group and at $3054 \mathrm{~cm}^{-1}$ assigned to $\mathrm{NH}_{3}{ }^{+}$stretching vibration in the spectrum. Presence of aromatic and aliphatic $\mathrm{C}-\mathrm{H}$ stretching vibrations at 2960 and $2316 \mathrm{~cm}^{-1}$ respectively and strong, peak at $1616 \mathrm{~cm}^{-1}$ due to $\mathrm{C}=\mathrm{O}$ group were seen in the spectrum. Asymmetric bendings for $\mathrm{NH}_{3}{ }^{+}$were observed in 1660 . Symmetric stretching of $\mathrm{COO}^{-}$at $1407 \mathrm{~cm}^{-1}$, strong peaks at $1119 \mathrm{~cm}^{-1}$ and $1038 \mathrm{~cm}^{-1}$ were assigned to aromatic C-N stretching vibration and C-O stretching vibration of the carbonyl group in the recorded IR spectrum of $\mathrm{Mn}$ (II) doped $\mathrm{ZnLHICl}$ crystal. A broadband from 3200 to $2100 \mathrm{~cm}^{-1}$ was assigned to asymmetric and symmetric stretching vibrations of $\mathrm{O}-\mathrm{H}, \mathrm{N}-\mathrm{H}$, and CH. Ring asymmetric stretching, symmetric stretching and ring deformation were observed at 953, 868 and $616 \mathrm{~cm}^{-1}$ respectively in the spectrum. Shifts were noticed in the distinctive vibrational frequencies of the FT-IR spectrum of Mn (II) doped ZnLHICl crystal compared to LHICl. These shifts were attributed to the changes in the nature of bonding due to complexation and doping. Coordination of LHICl ligand in a tridentate manner with $\mathrm{Zn}$ (II) ion was evident from the shifts in the resonance frequencies of coordinating groups. ${ }^{27}$ Shifts in the frequencies from $3157 \mathrm{~cm}^{-1}$ to $3132 \mathrm{~cm}^{-1}$ for NH of amine, from 1143 to $1119 \mathrm{~cm}^{-1}$ for imidazole nitrogen and for carboxyl oxygen from 1637 to $1616 \mathrm{~cm}^{-1}$ were observed supporting the coordination of these groups to $\mathrm{Zn}$ (II) ion and the values are shown in Table-3.

Table-3: Observed Vibrational Modes of LHICl and Mn(II) Doped ZnLHICl Crystals

\begin{tabular}{|c|c|c|}
\hline $\operatorname{LHICl}\left(\mathrm{cm}^{-1}\right)$ & $\begin{array}{c}\mathrm{Mn}(\mathrm{II}) \text { Doped } \\
\mathrm{Zn} \text { LHICl }\left(\mathrm{cm}^{-1}\right)\end{array}$ & Assignments \\
\hline 3411 & 3398 & O-H Stretching water \\
\hline 3157 & 3132 & N-H stretching \\
\hline 3106 & 3054 & $\mathrm{NH}_{3}{ }^{+}$stretching \\
\hline 3019 & 2960 & Aromatic C-H Stretching \\
\hline 2712 & 2316 & Aliphatic C-H Stretching \\
\hline 2009 & 1822 & Overtones and combination modes \\
\hline 1637 & 1616 & $\mathrm{C}=\mathrm{O}$ stretching \\
\hline 1606 & 1660 & Asymmetric bending of $\mathrm{NH}_{3}{ }^{+}$ \\
\hline 1497 & 1469 & Symmetric bending of $\mathrm{NH}_{3}{ }^{+}$ \\
\hline 1414 & 1407 & Symmetric stretching of $\mathrm{COO}^{-}$ \\
\hline 1143 & 1119 & C-N stretching \\
\hline 1064 & 1038 & C-O Stretching of the carbonyl group \\
\hline 959 & 953 & Ring asymmetric stretching \\
\hline 867 & 868 & Ring symmetric stretching \\
\hline 834 & 830 & C-C-O stretching \\
\hline 630 & 616 & Ring deformation \\
\hline
\end{tabular}

\section{UV-VIS Spectral Studies}

Transparency range and the presence of metal ions with characteristic absorption of a crystal can be determined using UV-Visible spectral study ${ }^{44}$. $\mathrm{Mn}$ (II) is a d ion and the spectral terms correspond to ${ }^{2} \mathrm{P}$, ${ }^{2} \mathrm{D},{ }^{2} \mathrm{~F},{ }^{2} \mathrm{H},{ }^{4} \mathrm{P},{ }^{4} \mathrm{D},{ }^{4} \mathrm{~F},{ }^{4} \mathrm{G}$ and ${ }^{6} \mathrm{~S}$. In weak crystal fields, the terms get transformed as ${ }^{6} \mathrm{~S} \rightarrow{ }^{6} \mathrm{~A}_{1 \mathrm{~g}},{ }^{4} \mathrm{G}$ $\rightarrow{ }^{4} \mathrm{~T}_{1 \mathrm{~g}}{ }^{4} \mathrm{~T}_{2 \mathrm{~g}}+{ }^{4} \mathrm{E}_{\mathrm{g}}+{ }^{4} \mathrm{~T}_{1 \mathrm{~g}},{ }^{4} \mathrm{D} \rightarrow{ }^{4} \mathrm{~T}_{2 \mathrm{~g}}+{ }^{4} \mathrm{E}_{\mathrm{g}}$ and ${ }^{4} \mathrm{P} \rightarrow{ }^{4} \mathrm{~T}_{1 \mathrm{~g}}$. Of the above terms, ${ }^{6} \mathrm{~A}_{1 \mathrm{~g}}$ lies lowest in accordance with Hund's rule and is the ground state for $\mathrm{Mn}$ (II) ion. When spin-orbit interaction turns slighter than electronic repulsion the crystal field is termed weak, otherwise, it is termed strong. If crystal field influence is in between spin-orbit interaction and electronic repulsion it is treated as an intermediate field. The transitions from the ground to doublet states are spin forbidden, too weak to be seen in the spectrum and weak sextet-quartet transitions can be observed for $\mathrm{Mn}$ (II) ion. ${ }^{45,46}$ The optical absorption spectrum of $\mathrm{Mn}$ (II) doped Zn HICL crystal is shown in Fig.-5. Three weak absorptions at 345, 405 and $455 \mathrm{~nm}$ were attributed to $\mathrm{Mn}(\mathrm{II})$ ion in an octahedral symmetry. ${ }^{47,48}$ The bands at $455 \mathrm{~nm}$ corresponds to ${ }^{6} \mathrm{~A}_{1} \mathrm{~g}(\mathrm{~s}) \rightarrow$ 400 
RASĀYAN J. Chem.

Vol. 13 | No. 1 |395 - 404| January - March | 2020

${ }^{4} \mathrm{~T}_{1} \mathrm{~g}(\mathrm{G})$, at $405 \mathrm{~nm}$ to ${ }^{6} \mathrm{~A}_{1} \mathrm{~g}(\mathrm{~s}) \rightarrow{ }^{4} \mathrm{E}_{\mathrm{g}}$ and at $345 \mathrm{~nm}$ to ${ }^{6} \mathrm{~A}_{1} \mathrm{~g}(\mathrm{~s}) \rightarrow{ }^{4} \mathrm{~A}_{2} \mathrm{~g}$ (D) transitions for $\mathrm{Mn}$ (II) ion in the optical absorption spectrum and agreed well with the reported values for $\mathrm{Mn}(\mathrm{II})$ ion. ${ }^{49}$ Crystal field $(\mathrm{Dq})$ and Racah parameters $(\mathrm{B}, \mathrm{C})$ with the Trees correction factor $[\alpha]$ for $\mathrm{Mn}(\mathrm{II})$ ion were evaluated, $\mathrm{Dq}$ $=850, \mathrm{~B}=820, \mathrm{C}=2500 \mathrm{~cm}^{-1}$ and $\alpha=76 \mathrm{Cm}^{-1}$ and the values are given in Table- 4 . The calculated parameters agreed well with the experimental data.

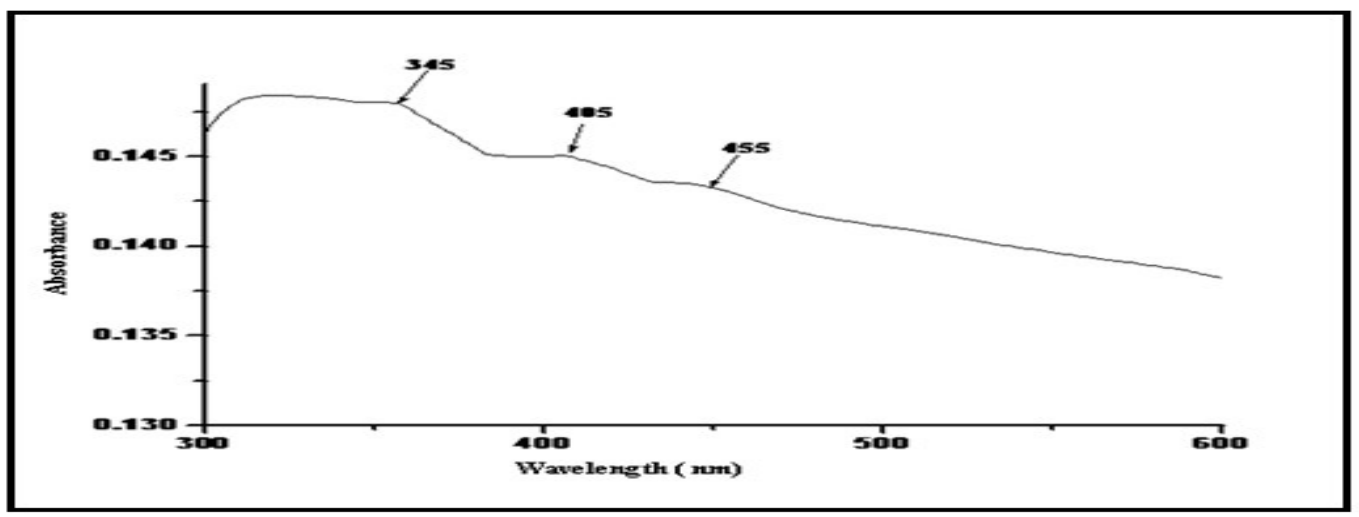

\section{Microhardness Studies}

Fig.-5: UV-VIS Spectrum of Mn(II) Doped ZnLHICl Crystal

Mechanical properties of NLO crystals which are determined by their hardness prove their suitability for fabrication devices. ${ }^{50} \mathrm{~A}$ higher value of hardness of a crystal specifies appreciable stress requirement to develop dislocation, which in turn confirms substantial crystalline perfection. ${ }^{51}$ The equation $\mathrm{Hv}=1.8544$ $\mathrm{P} / \mathrm{d}^{2}$ is used for calculation of the hardness of a crystal.

Microhardness, measured in terms of Vicker's hardness number Hv, indentation load is P in $\mathrm{Kg}$ and $\mathrm{d}$, the diagonal length, taken as an average of several impressions made. Microhardness results showed that hardness increased with increasing loads up to the applied load of $\mathrm{P}=52.2 \mathrm{~g}$ with a value for $\mathrm{Hv}=46$ $\mathrm{kg} / \mathrm{mm}^{2}$. After an applied load of $\mathrm{P}=52.2 \mathrm{~g}, \mathrm{Hv}$ value showed a decreasing trend, rupture as crevices observed due to the release of local inner stress which can, in turn, lead to indentation, which decreases the hardness value. ${ }^{52}$ The variation of microhardness with applied load for the $\mathrm{Mn}$ (II) doped $\mathrm{ZnLHICl}$ complex crystal is shown in Fig.-6.

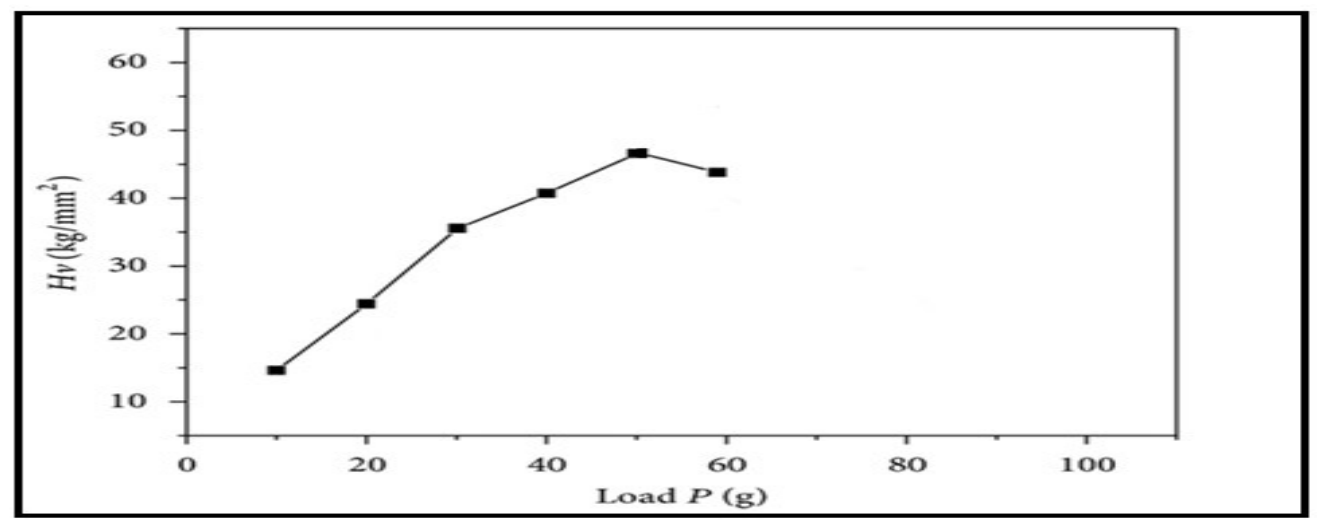

Fig.-6: Microhardness Studies of Mn(II) Doped ZnLHICl Crystal

Table-4: Optical Absorption Data of Mn(II) Doped ZnLHICl Crystal

\begin{tabular}{c|c|c|c}
\hline \multirow{2}{*}{ Transitions for Mn(II) Ion } & \multirow{2}{*}{ Wavelength $(\mathrm{nm})$} & \multicolumn{2}{|c}{ Wave Number $\left(\mathrm{cm}^{-1}\right)$} \\
\cline { 3 - 4 } & & Observed & Calculated \\
\hline${ }^{6} \mathrm{~A}_{1 \mathrm{~g}}(\mathrm{~S}) \rightarrow{ }^{4} \mathrm{~T}_{2 \mathrm{~g}}(\mathrm{D})$ & 445 & 22216 & 29746 \\
\hline${ }^{6} \mathrm{~A}_{1 \mathrm{~g}}(\mathrm{~S}) \rightarrow{ }^{4} \mathrm{E}_{\mathrm{g}}(\mathrm{G})$ & 405 & 24684 & 24996 \\
\hline${ }^{6} \mathrm{~A}_{1 \mathrm{~g}}(\mathrm{~S}) \rightarrow{ }^{4} \mathrm{~T}_{1 \mathrm{~g}}(\mathrm{G})$ & 455 & 21972 & 22220 \\
\hline \multicolumn{2}{c}{$\mathrm{Dq}=850 \mathrm{~cm}^{-1}, \mathrm{~B}=820 \mathrm{~cm}^{-1}, \mathrm{C}=2500 \mathrm{~cm}^{-1}$ and $[\alpha]=76 \mathrm{~cm}^{-1}$} \\
\hline
\end{tabular}


RASĀYAN J. Chem.

Vol. 13 | No. 1 | 395 - 404| January - March | 2020

\section{CONCLUSION}

1. $\mathrm{Zn}(\mathrm{II}) \mathrm{L}-\mathrm{Histidine}$ complex is the host lattice and $\mathrm{Mn}$ (II) is chosen as a dopant ion for the study. Colorless crystals of $\mathrm{Mn}(\mathrm{II})$ doped $\mathrm{ZnLHICl}$ with dimensions $10 \times 9 \times 6 \mathrm{~mm}^{3}$ are obtained by slow evaporation at room temperature.

2. Powder X-ray diffraction study revealed sharp patterns with small variations in the evaluated lattice cell parameters from LHICl indicating inclusion of dopant metal ions. A marginal decrease in volume for the $\mathrm{Mn}(\mathrm{II})$ doped crystals compared to LHICl suggests strong interactions in the molecule. An orthorhombic system with a space group $\mathrm{P} 22_{1} 2_{1} 2_{1}$ is proposed for $\mathrm{Mn}$ (II) doped $\mathrm{ZnLHICl}$ crystals.

3. EPR spectrum with resonance lines at $\mathrm{g}=1.9862$ suggests a close octahedral symmetry for the $\mathrm{Mn}$ (II) ions in the host lattice and positive value of $\Delta \mathrm{g}$ suggests covalent nature of bonding in the $\mathrm{Mn}$ (II) doped Zn LHICL crystals.

4. Shifts in FTIR characteristic vibrational frequencies of $\mathrm{Mn}(\mathrm{II})$ doped $\mathrm{ZnLHICl}$ crystal compared to $\mathrm{LHICl}$ indicates the coordination of L-Histidine in a tridentate manner by $\mathrm{NH}$ of amine, imidazole nitrogen and carboxyl oxygen to $\mathrm{Zn}(\mathrm{II})$ ion.

5. Characteristic transitions for $\mathrm{Mn}$ (II) ion in the UV-Vis spectrum and the calculated crystal field (Dq) and Racah parameters $(\mathrm{B}, \mathrm{C})$ for both the ions indicate octahedral symmetry of Mn(II) ions in the host lattice.

\section{ACKNOWLEDGMENT}

The University Grants Commission- New Delhi is very much appreciated for awarding the Faculty Research Grant to conduct this research work, through UGC-MRP/ F.No. 37-7/2009(SR), J. Sai Chandra particularlygrateful to UGC, New Delhi, for financial assistance through Non-SAP meritorious fellowship/Ref. No. F.4-1/2006(BSR).

\section{REFERENCES}

1. X. Lai, K.J. Roberts, L.H. Avanci, L.P. Cardoso and J.M. Sasaki, Journal of Applied Crystallography, 36(5), 1230(2003), DOI:10.1107/S0021889803014766

2. D.A.H. Cunningham, R.B Hammond, X. Lai and K.J. Roberts, Chemistry Materials, 7(9),1690(1995), DOI:10.1021/cm00057a018

3. X. Lai, K.J. Roberts, J.M. Bedzyk, P.F. Lyman, L.P. Cardoso and J.M. Sasaki, Chemistry Materials, 17(16), 4053(2005), DOI:10.1021/cm0478881

4. C.M.R. Remedios, W. Paraguassu, P.T.C. Freire, J. Mendes-Filho, J.M. Sasaki and F.E.A. Melo, Physical Review B, 72(1), 014121(2005), DOI:10.1103/PhysRevB.72.014121

5. M.L. Caroline, R. Sankar, R.M. Indirani and S.Vasudevan; Materials Chemistry and Physics, 114(1), 490(2009), DOI:10.1016/j.matchemphys.2008.09.070

6. P.C. Thomas, S. Aruna, J. Madhavan, Reena Ittyachan, Joseph Arul Pragasam, Joe G M Jesudurai, K.Prabha and P.Sagayaraj, Indian Journal of Pure and Applied Physics, 45(7), 591(2007)

7. Ittyachan Reena, S. X. Jesu Raja, S. A. Rajasekar and P. Sagayaraj, Material Chemistry and Physics, 90(1), 10(2005), DOI:10.1016/j.matchemphys.2004.04.025

8. H.O. Marcy, M.J. Rosker, L.F. Warren, P.H. Cunningham and C.A. Thomas, Optic Letters, 20(3) 252(1995), DOI:10.1364/OL.20.000252

9. S. Goma, C.M. Padma, C.K. Mahadevan, Material Letters, 60(29-30), 3701(2006), DOI: 10.1016/j.matlet.2006.03.092

10. M. Vazquez, D. Rothman and B. Imperiali, Organic and Biomolecular Chemistry, 2,1965(2004). DOI: $10.1039 / \mathrm{B} 408001 \mathrm{G}$

11. L.Antolini, G. Marcotrigiano, L. Menabue and G.C. Pellacani, Inorganic Chemistry, 22(20) 141(1983), DOI:10.1021/ic00162a037

12. C.A. Heyneman, Animal Pharmacotherapy, 30(2), 186(1996), DOI: 10.1177/1060028 09603000215

13. H.H. Sandstead, Journal of Laboratory and Clinical Medicine, 124(3), 322(1994), DOI:10.4236/ ajps. 2015.68118

14. Institute of Medicine, Food and Nutrition Board Dietary Reference Intakes, National Academy Press., Washington D.C, The Essential Guide to Nutrient Requirements 1-28 (2001)

15. N.W.Solomons, Nutritional Reviews., 56(1), 27(1998), DOI:10.1111/j.1753-4887.1998.tb01656.x

16. A.S. Prasad; Nutrition, 11,93(1995), DOI:10.4236/ajps.2015.68118 
RASĀYAN J. Chem.

Vol. 13 | No. 1 |395 - 404| January - March | 2020

17. R.J. Williams, J.P. Spencer and F.M. Goni and Rice-Evans CA, Neuroscience Letters, 371(2-3), 106(2004), DOI:10.1016/j.neulet.2004.08.054

18. J. R. Pinheiro, E. W. S. Caetano, V. N. Freire, G. A. Farias, K.Krambrock, M. C. F. de Oliveira, J. A. Pinheiro, B. S. Cavada and J. L. de Lima Filho; Applied Physics Letters, (Submitted)

19. K. Krambrock, K. J. Guedes, L. O. Ladeira M. J. B. Bezerra, T. M. Oliveira, G. A. Bezerra, B. S. Cavada, M. C. F. de Oliveira, M. Z. S. Flores, G. A. Farias and V. N. Freire; Physical review B, 75(10-1), 104205(2007), DOI:10.1103/PhysRevB.75.104205

20. D. Sergio Dalosto, Rafael Calvo, L.J.Pizarro and I. Mari Arriortua, Journal of Physics and Chemistry $A, \mathbf{1 0 5 ( 6 ) , ~ 1 0 7 4 ( 2 0 0 1 ) , ~ D O I : 1 0 . 1 0 2 1 / j p 0 0 3 1 6 7 n ~}$

21. Izhar Hussian and Margaret goodgame, Inorganica Chimica Acta, 174(2), 245(1990), DOI: $10.1016 / \mathrm{S} 0020-1693(00) 80307-2$

22. Donohue, L. R. Lavine and J. S. Rollett, Acta Crystallographica, 9 655(1956), DOI: $10.1107 / \mathrm{S} 0365110 \mathrm{X} 56001765$

23. V.Renuga, International Journal of Scientific and Research Publications, 4(7), 9(2014)

24. S.S. Hussaini, K. Datta, P. Ghosh, S. B. Kadam and M.D. Shirsat, International Conference on Optics and Photonics, Chandigarh, India, (2009).

25. K.D. Parikh, D.J. Dave, B.B. Parekh and M.J. Joshi; Crystal Research and Technology, 45(6), 603(2010), DOI:10.1002/crat.201000019

26. C.M.R. Remedios, W. Paraguassu, J.A. Lima Jr, P.T.C. Freire, J. Mendes-Filho, F . E. A. Melo, A. S. De Menezes, A.O. Dos Santos, L.P. Cardoso and M.A.R. Miranda, Journal of Physics: Condensed Matter, 20(27), 275209(2008), DOI:10.1088/0953-8984/20/27/275209

27. C. Alosious Gonsago, Helen Merina Albert, R. Umamaheswari and A. Joseph Arul Pragasam; Journal of Thermal Analysis and Calorimetry, 110(2), 839(2011), DOI:10.1007/s10973 -011-1850-9

28. D. Pathinettam Padiyan, C. Muthukrishnan and R. Murugesan; Spectrochimica Acta Part A: Molecular and Biomolecular Spectroscopy, 58(3), 509(2002), DOI:10.1016/S1386-1425(01)00549-2

29. T. K. Gundu and P. T. Manoharan, Chemical Physics Letters, 264(3-4), 338(1997), DOI: 10.1016/S0009-2614(96)01348-6

30. B. Wagner, S. A. Warda, M. A. Hitchman and D. Reinen; Inorg. Chem., 35(13), 3967(1996), DOI: $10.1021 /$ ic951418e

31. J. Lech, A. Slezak and R. Hrabanski; Journal of Physics and Chemistry Solids, 66(5), 876(2005), DOI:10.1016/j.jpcs.2004.10.011

32. F. E. Mabbs and D. Collison; Electron paramagnetic resonance of d transition metal complexes, Elsevier, Amsterdam (1992).

33. A. Abragam and B. Bleaney; Elec. Paramag. Res. Trans., Clarendon Press, Oxford, UK (1970).

34. J.R. Pilbrow; Trans. Ion Elec. Paramag. Res., Clarendon Press, Oxford, UK, (1990).

35. B.R. McGarvey and R.L. Carlin, Transition Metal Chemistry, Third edition, 89(1966).

36. H. Anandalakshmi, K. Velavan, I. Sougandi, R. Venkatesan, P. Sambashiva Rao and Pramana, Journal of Physics, 62(1), 77(2004), DOI:10.1007/BF02704427

37. T.A. Stich, S. Lahari, G. Yeagle, M. Dicus, M. Brynda, A. Gunn, C. Aznar, V.J. Derose and R.D. Britt, Applied Magnetic Resonance, 31, 321(2007), DOI:10.1007/BF03166263

38. R.V.S.S.N.Ravikumar, K. Ikeda, A.V. Chandrasekhar, Y.P. Reddy, P.S. Rao and Jun Yamauchi, Journal of Physics and Chemistry Solids, 64(12), 2433(2003), DOI:10.1016/S0022-3697(03)00286-5

39. Shiv Prakash Singh, R. P. S. Chakradhar, J. L. Rao and Basudeb Karmakar, Physica B: Condensed Matter, 405(9), 2157(2010), DOI: 10.1016/j.physb.2010.01.123

40. D. Viviani, F. Faivre, C. Levelut and M. Smaihi; Journal of Physical chemistry.B, 110(14), (2006) 7281, DOI: $10.1021 /$ jp055835g

41. L.J.Bellamy; The Infrared Spectra of Complex Molecules., 3rd ed.New York: Wiley, (1975).

42. G.Herzberg; Infrared and Raman Spectra of Polyatomic Molecules,1st edition, New York: Van Nostrand Reinhold (1945).

43. C.N.R.Rao; Chemical Application of Infrared Spectroscopy, 2nd Edition, New York: Academic Press, (1963).

44. C.N.R.Rao., Ultraviolet and Visible Spectroscopy, Chemical Applications, Plenum Press, (1975) 
RASĀYAN $J$. Chem.

Vol. 13 | No. 1 |395 - 404| January - March | 2020

45. D.S. Mc Clure, F. Seitz and P. Turnbull, Academic Press, New York, 9, 502(1959).

46. A.B.P. Lever, Inorganic Spectroscopy, Elsevier, Amsterdom, 292(1968).

47. Y.Tanabe and S.Sugano, Journal of Physical Society of Japan, 9(5), 753(1954), DOI: 10.1143/JPSJ.9.753

48. B.Natarajan, S.Mithira and P.Sambasiva Rao, Physica Scripta, 83(6), 8(2011), DOI: $10.1088 / 0031-8949 / 83 / 06 / 065704$

49. W.Low and G. Rosengarten, Journal of Molecular Spectroscopy, Journal of Molecular Spectroscopy, 12(4), 319(1964), DOI:10.1016/0022-2852(64)90018-9

50. P.Rajesh and P.Ramasamy, Physica B: Condensed Matter 404(8-11), 1611(2009), DOI: 10.1016/j.physb.2009.01.032

51. G. Anandha Babu, Journal of Crystal Growth, 310(6), 1228(2008), DOI: $10.1016 /$ j.jcrysgro.2007.12.024

52. P. Anandan, G. Parthipan, T. Saravanan, R. Mohan Kumar, G. Bhagavan narayana and R. Jayavel, Physica B: Condensed Matter, 405(24), 4951(2010), DOI:10.1016/j.physb. 2010.09 .042

[RJC-5197/2019] 